\title{
Adaptations to Endurance and Strength Training
}

\author{
David C. Hughes, ${ }^{1}$ Stian Ellefsen, ${ }^{2,3}$ and Keith Baar ${ }^{1}$ \\ ${ }^{1}$ Department of Neurobiology, Physiology and Behavior, Functional Molecular Biology Laboratory, University \\ of California Davis, Davis, California 95616 \\ ${ }^{2}$ Section of Sports Sciences, Lillehammer University College, 2604 Lillehammer, Norway \\ ${ }^{3}$ Innlandet Hospital Trust, 2380 Brumunddal, Norway \\ Correspondence: kbaar@ucdavis.edu
}

\begin{abstract}
The capacity for human exercise performance can be enhanced with prolonged exercise training, whether it is endurance- or strength-based. The ability to adapt through exercise training allows individuals to perform at the height of their sporting event and/or maintain peak physical condition throughout the life span. Our continued drive to understand how to prescribe exercise to maximize health and/or performance outcomes means that our knowledge of the adaptations that occur as a result of exercise continues to evolve. This review will focus on current and new insights into endurance and strength-training adaptations and will highlight important questions that remain as far as how we adapt to training.
\end{abstract}

In response to exercise, humans alter the phenotype of their skeletal muscle; changing the store of nutrients, amount and type of metabolic enzymes, amount of contractile protein, and stiffness of the connective tissue, to name but a few of the adaptations. The shift in phenotype is the result of the frequency, intensity, and duration of the exercise in combination with the age, genetics, gender, fueling, and training history of the individual (Joyner and Coyle 2008; Brooks 2011). Therefore, even though exercise is often referred to as a single stimulus and we have looked for generalized responses, how any individual responds to exercise training will vary based on things we understand and (likely) many more that we do not. As is the norm, this article will focus on the things that we already understand, but will highlight important questions that remain as far as how we adapt to training.
Exercise is generally separated into aerobic/ endurance and power/strength activities. Endurance exercise is classically performed against a relatively low load over a long duration, whereas strength exercise is performed against a relatively high load for a short duration. However, pure endurance and pure strength exercise is rare. Most activities combine endurance and strength and this type of training has been termed concurrent exercise. Furthermore, recent work showing that short high-intensity exercise can lead to endurance adaptations and low-load exercise that approaches failure can lead to strength adaptations has challenged our understanding of which type of exercise results in which phenotypic shift in muscle. Classic endurance training is known to result in enhanced cardiac output, maximal oxygen consumption, and mitochondrial biogenesis

Editors: Juleen R. Zierath, Michael J. Joyner, and John A. Hawley

Additional Perspectives on The Biology of Exercise available at www.perspectivesinmedicine.org

Copyright (C) 2018 Cold Spring Harbor Laboratory Press; all rights reserved; doi: 10.1101/cshperspect.a029769

Cite this article as Cold Spring Harb Perspect Med 2018;8:a029769 
D.C. Hughes et al.

(Holloszy 1967; Coyle et al. 1983, 1986, 1988; Holloszy and Coyle 1984; Favier et al. 1986). The overall improvement in both central and peripheral tissues allows for enhanced exercise economy and a greater ability for an individual to run for longer distances and times (Brooks 2011). In contrast, strength training results in increases in muscle size (cross-sectional area [CSA]), neural adaptations (motor output), and improved strength (maximal force production) (Narici et al. 1989; Staron et al. 1991; Pyka et al. 1994; Häkkinen et al. 1998a). These positive alterations in physical capacity allow an individual to be stronger, more powerful, and maintain a better quality of life throughout the life span (Visser et al. 2005; Goodpaster et al. 2006; Newman et al. 2006).

Indeed, both endurance and strength-training adaptations not only contribute toward potential sporting excellence but, in most instances, contribute toward the delayed onset of age-related diseases (McGregor et al. 2014; Zampieri et al. 2015; Cartee et al. 2016). This article focuses on recent concepts and new literature in the field of endurance and strength training and how this new information has changed the dogma of how exercise enhances physical performance and overall adaptation. Finally, the combination of endurance and strength exercise and recent advances in our understanding of concurrent training will also be briefly discussed in the latter part of this article.

\section{ENDURANCE TRAINING}

Endurance training leads to adaptations in both the cardiovascular and musculoskeletal system that supports an overall increase in exercise capacity and performance (Brooks 2011). The local adaptations in skeletal muscle, such as increased mitochondrial biogenesis and capillary density, aid in the body's ability to transport and use oxygen to generate energy and therefore delay the onset of muscle fatigue during prolonged aerobic performance (Joyner and Coyle 2008). The mitochondrion is the main organelle for energy production through the generation of adenosine triphosphate (ATP) via the electron transport system (ETS), using substrates generated in the tricarboxylic acid (TCA) cycle (Egan and Zierath 2013; Bishop et al. 2014). Recent studies have begun to investigate the impact of exercise-induced mitochondrial biogenesis adaptations from the perspective of mitochondrial content and function with varying exercise intensity paradigms (Serpiello et al. 2012; Granata et al. 2016a,b; MacInnis et al. 2016). Studies investigating the role of the intensity and volume of exercise on mitochondrial adaptations have been conducted using long slow-distance (LSD) training, sprint interval training ([SIT]; $\sim 30 \mathrm{sec}$ maximal bouts) and high-intensity interval training (HIIT; 1-4 min all-out bouts) (Gibala et al. 2014). Traditional LSD training entails an individual sustaining a submaximal workload for a long period of time, or successfully completing a fixed distance/time through a higher than average power output (Coyle 1995). On the other hand, HIIT and SIT require the individual to perform repeated bouts at close to maximal intensity for a short period of time with a reduced training volume (Laursen and Jenkins 2002; Gibala et al. 2006). Many studies have highlighted similarities in adaptations for mitochondria markers (e.g., peroxisome proliferator-activated receptor $\gamma$ coactivator $1 \alpha$ [PGC-1 $\alpha]$ ) and skeletal muscle oxidative capacity in both training models (Gibala et al. 2009; Little et al. 2010b, 2011; Jacobs et al. 2013b; Cochran et al. 2014), and, therefore, HIIT/SIT has been proposed as a time-effective strategy for enhancing aerobic adaptations (Gibala and McGee 2008; Gillen and Gibala 2013).

More recent studies have begun to directly address the importance of exercise intensity versus volume in relation to mitochondrial content and function (Daussin et al. 2008; Jacobs et al. 2013b; Cochran et al. 2014; Granata et al. 2016b; MacInnis et al. 2016). Granata and colleagues (2016b) used all three exercise protocols (LSD, HIIT, and SIT), matching volume in the traditional and HIIT groups, on young moderately trained men. After $4 \mathrm{wk}$ of training, the investigators observed a $25 \%$ increase in maximal mitochondrial respiration only in the SIT group, with no changes seen in either the LSD or HIIT groups. The increased level of mito- 
chondrial respiration within the SIT group was accompanied by changes in PGC- $1 \alpha$, p 53 , and PHF20 protein content. PHF20 is important for both stabilizing and up-regulating p53 (Cui et al. 2012; Park et al. 2012), whereas p53 is a tumor suppressor and involved in the regulation of mitochondrial function (Matoba et al. 2006; Park et al. 2009). In contrast to the Granata study, HIIT alone has been shown to influence mitochondrial content and respiration (Daussin et al. 2008; Jacobs et al. 2013b). Jacobs et al. (2013b) observed increased mitochondrial respiration along with alterations in content (measured by cytochrome $c$ oxidase [COX] activity) culminating in increased exercise capacity after only 2 wk of HIIT training. Further support for mitochondrial adaptations with HIIT comes from a within-subject study that showed 2 wk of training resulted in increased mitochondrial volume density and respiration (MacInnis et al. 2016). The discrepancies between these studies may be because of differences in subject training status, experimental design, and methodological measures implemented for assessing mitochondrial adaptations. The optimal study to conclusively address this issue would use all three training models and a within-subject crossover design.

When the intensity of training is maintained and only the volume manipulated, the mitochondrial adaptation differs again, using a design in which 10 subjects performed HIITonce a day three times a week, then twice a day three times a week, followed by once a day two times a week. Granata and colleagues (Granata et al. 2016b) showed that mitochondrial respiration and citrate synthase (CS) activity increased ( $\sim 50 \%$ ) during only the high-volume training period. The increase in mitochondrial respiration was accompanied by increased ETS and regulatory proteins, such as PGC- $1 \alpha$, p 53 , and PHF20. Following 2 wk of decreased training volume, mitochondrial-specific respiration remained high, with a slight decrease in CS activity being the only sign of detraining. Overall, these studies suggest that high-intensity training is important for increasing mitochondrial activity, whereas a greater training volume is needed to increase mitochondrial mass (Fig. 1)
(MacInnis et al. 2016). However, the predominant marker used to determine alterations in mitochondrial content has been CS activity. Future studies should look to use electron microscopy and identify other markers that may more be reflective of mitochondrial activity (e.g., subsarcolemma vs. intermyofibrillar location of mitochondria) and mass changes in skeletal muscle.

Classically, PGC- $1 \alpha$ has been anointed as the "master regulator of mitochondrial biogenesis" and a fundamental component of exerciseinduced adaptations with endurance training (Baar et al. 2002; Pilegaard et al. 2003; Little et al. 2010a). In recent years, another protein, p53, has emerged as a key player in substrate metabolism and mitochondrial biogenesis (Park et al. 2009; Saleem and Hood 2013; Bartlett et al. 2014). p53 was the first tumor suppressor protein discovered (Baker et al. 1989; Nigro et al. 1989). In this role, p53 regulates cell-cycle arrest, apoptosis, angiogenesis, DNA repair, and cell senescence (Levine et al. 2006). Initial studies using mouse knockout (KO) models lacking p53 identified a further role for this protein in controlling mitochondrial content, with $\mathrm{KO}$ mice displaying reduced mitochondria in both subsarcolemmal and intermyofibrillar compartments, together with reduced COX activity and PGC-1 $\alpha$ compared with wild-type animals (Saleem et al. 2009). Furthermore, the loss of p53 and subsequent decrease in mitochondrial content and function resulted in reduced exercise capacity and performance (Park et al. 2009). The current proposed mechanisms for how p53 may regulate mitochondrial biogenesis is through targeting the mitochondrial genome and specifically interacting with mitochondrial transcription factor A (Tfam) (Saleem and Hood 2013). Saleem and Hood (2013) reported that, with acute exercise and muscle contraction, p53 translocates from the nucleus and positively modulates Tfam activity. In terms of current human data, Bartlett et al. (2012) observed increased $\mathrm{p} 53$ phosphorylation $3 \mathrm{~h}$ postexercise, although this alteration in $\mathrm{p} 53$ phosphorylation occurred after acute bouts of both continuous endurance and HIIT exercise. In contrast, Granata and colleagues showed that p53 increases 
D.C. Hughes et al.

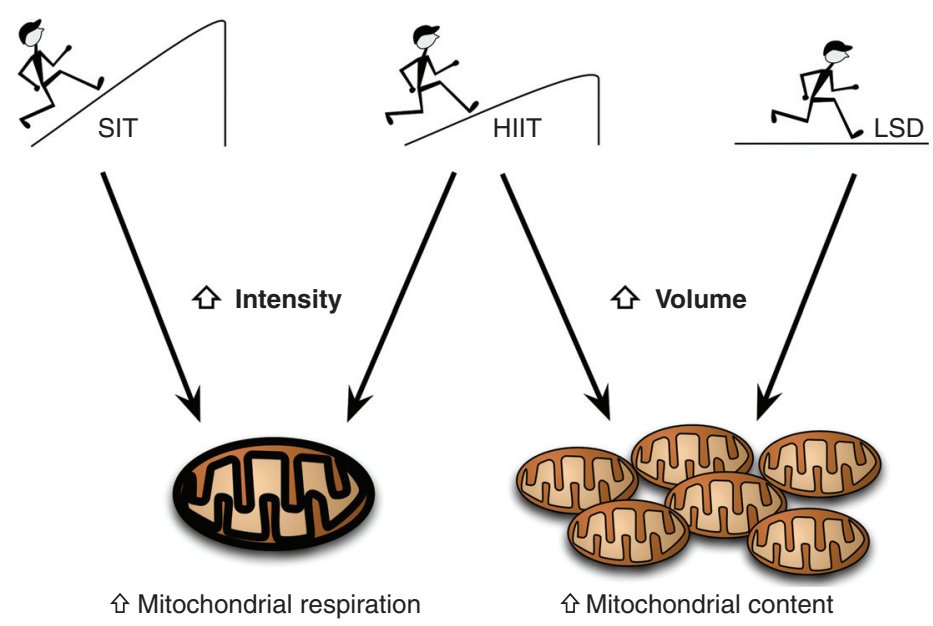

Figure 1. Schematic diagram of training intensity and volume on mitochondrial respiration versus content adaptations through endurance training. Recent evidence suggests that increases in exercise intensity (sprint interval training [SIT]; high-intensity interval training [HIIT]) lead to enhanced mitochondrial respiration and function, whereas prolonged low-intensity and high-volume (long slow-distance [LSD] training) endurance exercise appears to aid in increased mitochondrial content within skeletal muscle.

with maximal sprint training, whereas HIIT or continuous endurance training has no effect on p53 content (Granata et al. 2016b). It is important to note that the regulation of $\mathrm{p} 53$ may not only be influenced by exercise intensity but also the nutritional status of the working muscle during training sessions, for example, reduced carbohydrate availability (Bartlett et al. 2013). Future research is required to understand the time course of p53 activation and involvement in mitochondrial biogenesis with respect to endurance exercise (Bartlett et al. 2014). Understanding this signaling cascade will not only be important from a human performance perspective but also from a health standpoint in which exercise might be used to support treatments in cancer therapy (Saleem and Hood 2013).

In addition to alterations in oxygen delivery, substrate metabolism, and mitochondrial mass within skeletal muscle after endurance training, other factors contribute toward the resulting enhanced exercise performance and improved running economy (Saunders et al. 2004; Barnes and Kilding 2015). One such factor is the stiffness of the muscle-extracellular matrix (ECM)-tendon unit, because adaptations within this system will enhance the body's ability to store and use elastic energy more efficiently. An increase in elastic energy storage and recoil results in decreased ground contact time and reduced energy cost (Arampatzis et al. 2006; Fletcher et al. 2010). Indeed, runners who display and/or develop a longer and stiffer musculotendonous system appear to have a lower oxygen uptake $\left(\mathrm{VO}_{2}\right)$ when performing at submaximal running velocities (Craib et al. 1996; Albracht and Arampatzis 2013; Barnes et al. 2014). A second factor contributing to improved running and cycling economy is neural adaptation. Muscle recruitment patterns vary greatly between highly trained individuals and novice counterparts (Paavolainen et al. 1999b,c; Chapman et al. 2008). Highly trained individuals may have the capacity to elicit increased muscle coactivation, leg stiffness, and greater eccentric to concentric muscle activity, which allows for more efficient usage of stored elastic energy, lowering the metabolic cost of exercise (Paavolainen et al. 1999b; Heise et al. 2008). In contrast, stretching interventions used to enhance flexibility tend to decrease economy, although these results have been equivocal (Craib et al. 1996; Nelson et al. 2001; Shrier 2004). Some of the possible reasons for the contrasting evidence with stretch- 
ing include the length of intervention program (acute vs. chronic), the influence of gender in pooled studies, methodological designs, and treadmill familiarization (Craib et al. 1996; Nelson et al. 2001; Shrier 2004; Allison et al. 2008; Trehearn and Buresh 2009).

Training to improve the connective tissue stiffness and neuromuscular components is quite different than classic endurance training. Here, training is based on strength/power and plyometric exercises to heighten the neuromuscular adaptations (e.g., muscle activation, motor unit recruitment) and the stiffness of the muscle-ECM-tendon unit (Storen et al. 2008; Yamamoto et al. 2008; Beattie et al. 2014). A good example of this work is an early study by Paavolainen and colleagues (1999a) who investigated the impact of explosive-type strength training in well-trained endurance athletes on endurance performance $(5-\mathrm{km}$ time trial, running economy, etc.). After $9 \mathrm{wk}$ of training, the investigators reported a $3 \%$ improvement in $5-\mathrm{km}$ time trial with a tendency to decrease $\mathrm{VO}_{2 \max }$. The improved performance resulted largely from improvements in running economy. Subsequent research has highlighted an additive effect of incorporating a strengthtraining program into the training of predominately endurance-trained athletes, both during preseason and in season (Rønnestad et al. 2010). The proposed mechanisms for these improvements in endurance performance are improved neural function (maximal voluntary contraction, rate of force development [RFD]), increases in type IIA muscle fibers (less fatigable), and increased muscle-ECM-tendon stiffness (Aagaard and Andersen 2010; Aagaard et al. 2011). Further, the addition of strength training has been observed to improve exercise economy better than endurance training alone (Sunde et al. 2010; Beattie et al. 2014; Vikmoen et al. 2015) and the inclusion of strength training may enhance performance during the later stages of competition (Rønnestad et al. 2011). One way to distinguish between the muscleECM-stiffness and neural adaptations would be to perform the strength/plyometric training on one leg and determine whether cross-limb transfer has resulted in improved performance
Adaptations to Endurance and Strength Training

in the opposite limb indicative of a neural adaptation (see below). However, these experiments have yet to be performed with endurance-type exercise. Further, caution is warranted for strength training to improve endurance performance as there is also evidence to suggest that increasing endurance and strength training volume together may lead to impairments in both adaptations and performance (Hickson 1980; Rønnestad et al. 2012; Jones et al. 2013).

The last adaptation to endurance exercise training that we would like to highlight is muscle hypertrophy and growth (Harber et al. 2009b, 2012; Konopka and Harber 2014). Over a 12-wk endurance-training program, muscle mass has been reported to increase by $7 \%$ to $11 \%$ (Konopka et al. 2010; Trappe et al. 2011; Harber et al. 2012). This increase in muscle mass is comparable to resistance exercise training over the same time period (Trappe et al. 2011; Mitchell et al. 2012). These reported increases in muscle mass with endurance training have been predominately observed in the quadriceps muscle, the mode of exercise used was cycling, and the individuals undertaking training had a limited level of exercise experience and/or sedentary lifestyle (Konopka and Harber 2014). Nonetheless, it appears that hypertrophy occurs in the quadriceps muscle with classical motor endurance training if the frequency of training and load are high enough (Konopka and Harber 2014). From a mechanistic perspective, acute studies have reported increases in muscle protein synthesis (MPS) with aerobic exercise, independent of age (Short et al. 2004; Harber et al. 2009a, 2010; Durham et al. 2010). For example, Short and colleagues (2004) observed a $22 \%$ increase in MPS with 4 mo of cycling (up to $45 \mathrm{~min}$ at $80 \%$ peak heart rate, $3-4$ days/wk). The observed increases in MPS with aerobic exercise do not appear to be driven by complex 1 of the mechanistic target of rapamycin complex 1 (mTORC1) (Durham et al. 2010; Philp et al. 2015). Using rapamycin (an inhibitor of mTORC1 activation), Philp and colleagues (2015) reported increases in muscle and mitochondrial protein synthesis rates following endurance exercise in rats, even when mTORC1 signaling was completely suppressed. The find- 
D.C. Hughes et al.

ings by Philp and colleagues are in contrast with previous findings reporting increased MPS and mTORC1 activation with aerobic exercise (Mascher et al. 2011; Edgett et al. 2013; Di Donato et al. 2014). As mentioned previously with other facets of endurance adaptation, the impact of exercise intensity, modality, and level of muscle fiber recruitment may be a potential explanation for the contrast in findings between studies. Specifically, hypertrophy has been observed almost exclusively following training for cycling. Future studies should seek to implement other modes of endurance exercise such as running using different loads/ modes (uphill vs. flat) with the same volume to determine whether this affects MPS acutely and muscle size following training. From a mechanistic standpoint, subsequent studies will need to assess the contributions of feeding, myostatin signaling, and other mTOR-independent mechanisms toward endurance-related muscle hypertrophy.

\section{STRENGTH TRAINING}

Strength training leads to an increase in muscle strength and power as a result of neuromuscular adaptations, increases in muscle CSA, and alterations in connective tissue stiffness (Knuttgen and Kraemer 1987). The result is a rapid initial increase in strength as an individual learns an exercise (Fig. 2) (Sale 1988), followed by slowed progression as the muscle grows (Fry 2004; Folland and Williams 2007; Wernbom et al. 2007). Strength training has classically varied the external load and volume to enhance either the neuromuscular drive or muscle CSA, generally training with a load between $1 \mathrm{RM}$ (repetition maximum) to $10 \mathrm{RM}$ and a volume of four to 12 repetitions (Fry 2004). The adaptations to resistance training are generally evident after 8 to 12 wk (Häkkinen et al. 1998b; Folland and Williams 2007). However, some studies have observed increases in muscle strength and CSA after only 2 to 4 wk (Staron et al. 1994; Seynnes et al. 2007; DeFreitas et al. 2011; Brook et al. 2015; Damas et al. 2016). This early increase in strength is likely caused by neuromuscular and connective tissue adaptations (Sale 1988), whereas the early increases in muscle CSA size may be the result of edema (Damas et al. 2016).

Because of the rapid nature of the neuromuscular adaptations and the ability to mea-

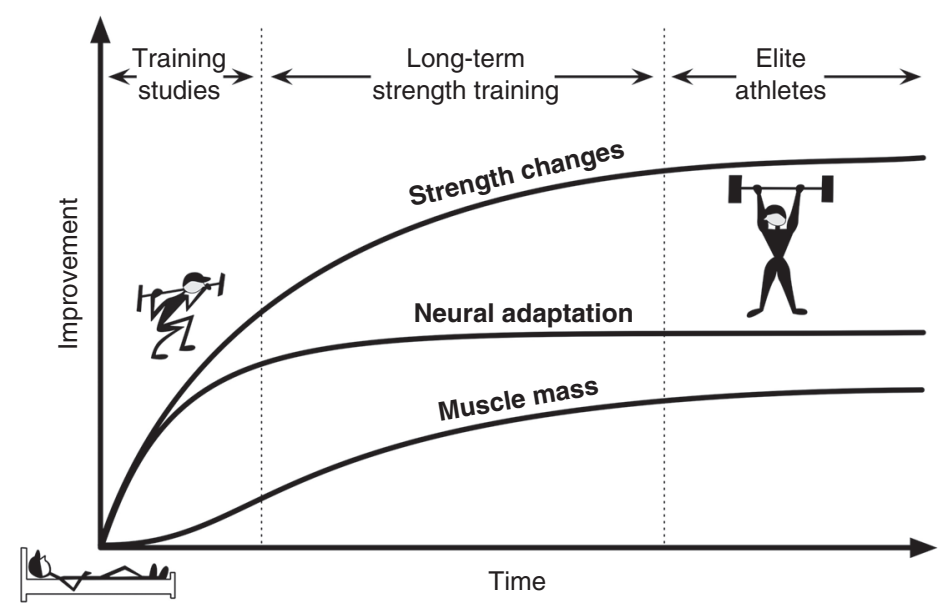

Figure 2. Alterations in strength, mass, and neural adaptations with resistance exercise over time. Resistance exercise studies ( 8 to $12 \mathrm{wk}$ of training) display an early increase in strength as a result of neural adaptations. With prolonged strength training, muscle mass slowly increases and drives the later changes in strength after neural adaptations begin to plateau. Finally, at the elite level, individuals show small changes in all three core adaptations that accompany strength training. At this point, new stimuli (possibly targeting the extracellular matrix $[\mathrm{ECM}])$ are needed to increase strength. 
sure changes in CSA, most early studies within this field have focused on these responses $(\mathrm{Cu}-$ reton et al. 1988; Narici et al. 1989; Staron et al. 1991, 1994). Adaptations observed within the neuromuscular system have centered on increases in skill acquisition through the nervous system and increased maximal muscle activation by way of motor unit synchronization, muscle recruitment, and increased neural activation (Enoka 1988; Jones et al. 1989). In terms of hypertrophy, the main focus for adaptation has been on increases in CSA for individual muscle fibers, adding sarcomeres in parallel (Cureton et al. 1988; Frontera et al. 1988; Staron et al. 1990). Early mechanistic studies focused on alterations within the hormone milieu after acute resistance exercise as a potential contributing factor toward hypertrophy (Kraemer et al. 1991; Häkkinen and Pakarinen 1993; McCall et al. 1999). However, recent evidence appears to cast doubt over the hypothesis that hormones contribute to exercise-induced muscle hypertrophy and growth (West et al. 2009, 2010, 2012; Schroeder et al. 2013; Morton et al. 2016).

The importance of the central neural component on strength adaptations is most evident when one limb is trained and the other limb goes untrained. In this situation, muscle CSA does not change in the untrained leg, yet a significant increase in strength occurs from training the contralateral limb (Houston et al. 1983; Yasuda and Miyamura 1983; Munn et al. 2004, 2005). A meta-analysis on the contralateral strength-training effect suggests that strength improves $7.6 \%$ in the nonexercised limb (56\% of what happens in the exercised limb), with training lasting for between 15 and 48 sessions (Munn et al. 2004; Carroll et al. 2006). Some of the proposed mechanisms for this phenomenon are localized muscle adaptations, crosslimb cortical interaction, and adaptations in spinal cord excitability (Carroll et al. 2006). Ultimately, the unilateral strength training may cause adaptations in neural drive that "spill over" into the untrained limb and, in addition, the untrained limb may access the neuromuscular adaptations that occur within the control system with this type of training (Carroll et al. 2006). Most recently, Kidgell and colleagues
(2015) highlighted a greater cross-transfer of strength with an eccentric (47\%) versus concentric $(28 \%)$ loading group. One of the possible reasons for the greater effect with eccentric loading was a larger increase in corticospinal excitability, which has been proposed as the mechanism underlying the effect (Latella et al. 2012). However, given that it was first observed in 1894 (Scripture et al. 1894), we still understand very little about the contralateral strengthtraining effect and the role of the systemic environment in this phenomenon (Yasuda and Miyamura 1983; West et al. 2015).

Another adaptation observed with strength training is an increase in the RFD (Aagaard et al. 2002; Suetta et al. 2004; Andersen and Aagaard 2006; Maffiuletti et al. 2016). The RFD refers to the rate of increase in force at the onset of contraction, that is, the slope of the force-time curve (Sleivert and Wenger 1994; Aagaard et al. 2002). An early study by Aagaard and colleagues (2002) demonstrated a 15\% increase in RFD after 14 wk of heavy strength training. In addition, there were increases in both EMG amplitude and rate of EMG increase with training, indicating an enhancement in neural drive. This suggests that RFD is related to alterations in neural drive. Other factors that contribute to RFD are muscle fiber type and force transfer. Studies on the role of fiber type indicate that type II fibers show a greater RFD (Korhonen et al. 2006; Aagaard et al. 2007); thus, increases in type II fiber CSA with strength training would complement the increased neural drive (Staron et al. 1990, 1991; Mero et al. 2013). Our understanding of how force transfer contributes to RFD is in its infancy (Hughes et al. 2015). The cytoskeletal network within muscle transmits force both along the length of each muscle fiber (longitudinally) and from the center to the outside of the fiber (laterally) (Hughes et al. 2015). Importantly, $>80 \%$ of force produced within a fiber is transferred laterally from proteins within the fiber to ECM proteins outside the fiber (Ramaswamy et al. 2011). Key components of the force transfer apparatus include intracellular proteins (titin, dystrophin, etc.), transitional complexes (dystrophin-associated glycoprotein complex [DAGC] and integrins), and extracel- 
D.C. Hughes et al.

lular proteins (collagens I, III, IV, V, and VI) (Fig. 3). Dystrophin is essential for lateral force transmission (Ramaswamy et al. 2011; Hughes et al. 2015), whereas titin and nebulin are more important for transmitting force longitudinally and the stiffness of the sarcomere (Ottenheijm et al. 2012; Herzog et al. 2016; Powers et al. 2016). The essential role of ECM proteins in RFD was most clearly shown by Mebes and colleagues (2008) in women with Ehlers-Danlos syndrome ( joint hypermobility). In this work, women with hypermobile joints showed a 15\% slower RFD with no difference in maximal force, showing the essential role of connective tissue in RFD. There is limited data on the adaptations of these cytoskeleton proteins to strength training, with some studies reporting no changes (McGuigan et al. 2003; Woolstenhulme et al. 2006) and other studies indicating improvements (Lehti et al. 2007; Kosek and Bamman 2008; Parcell et al. 2009; Macaluso et al. 2014). Interestingly, there is cross-sectional evidence for differing levels of force transfer proteins between trained and untrained athletes (McBride et al. 2003). However, more studies are required to address the influence of strength training on the cytoskeleton protein network and force transmission. This is especially true as these groups of proteins appear to play a key role in protecting against contraction-induced muscle injury and possibly in mechanotransduction (Lovering and De Deyne 2004; Boppart et al. 2006; Palmisano et al. 2015; Hughes et al. 2016).

As with endurance training, a shift in the existing muscle hypertrophy paradigm appears to be emerging because recent evidence suggests that load does not determine the increase in CSA that occurs with strength training. In these studies, lifting a low load to positive failure produces equal hypertrophy to using a high load and fewer repetitions to reach failure (Mitchell

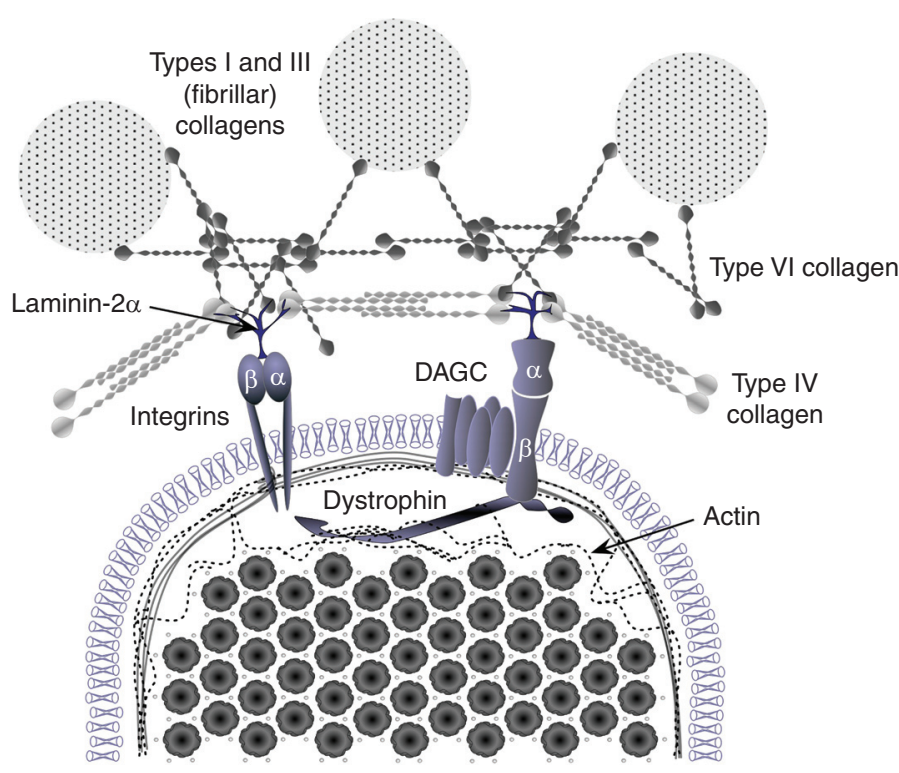

Figure 3. Interaction of the extracellular matrix (ECM), connective tissue, and cytoskeleton protein networks surrounding skeletal muscle myofibrils. Research on the cellular adaptations that occur with strength training have predominantly focused within skeletal muscle. Recent research has begun to highlight the role of the dystrophin-associated glycoprotein complex (DAGC) and integrin complexes in force transmission and the possible contribution of structures outside the muscle to force transfer and overall strength. Few studies have investigated the contribution of the ECM to muscle force transfer and/or how these complexes may adapt over a period of time with training. However, hyperlax individuals (with mutations in collagen VI) show slowed rates of force development, indicating that the ECM is important in muscle function. 
et al. 2012; Ogasawara et al. 2013; Schoenfeld et al. 2015; Morton et al. 2016). In the new paradigm, momentary muscular failure is important for hypertrophy. The hypothesis for the importance of failure centers on muscle fiber recruitment; at failure, all motor units are recruited regardless of the load (Counts et al. 2016). In an interesting recent investigation, Counts and colleagues (2016) used a "noload" intervention in which individuals repeatedly contracted a muscle as hard as they could through a full range of motion. The investigators observed similar increases in muscle thickness in the "no-load" and high-load groups. However, even though the increase in CSA with no-, low-, and high-load training is equivalent, high loads are needed to maximize strength gains (Schoenfeld et al. 2015). The effect of low-load training on muscle mass should not be surprising given the ability of cycling to increase muscle mass (see above); however, the molecular pathways that convert any load into a biochemical signal that results in muscle hypertrophy remain elusive. Acute studies have suggested that there is a load-dependent increase in mTORC1 activity after resistance exercise that correlates with the resulting increase in muscle mass following training (Baar and Esser 1999). The increase in mTORC1 activity is the result of signaling through a PI3K/Akt-independent RxRxxS/T kinase (Jacobs et al. 2013a). However, whether the increase in mTORC1 activity following acute resistance exercise is driving muscle hypertrophy or simply reflects the amount of injury and subsequent inflammatory response and how the mTORC1 response is altered by exercising to failure has yet to be shown. Similarly, the role of mTORC1-independent mechanisms, such as myostatin signaling and ribosomal biogenesis, requires more research before their role in training-induced muscle hypertrophy is understood.

\section{CONCURRENT TRAINING}

Simultaneously participating in both endurance and strength-training programs results in a similar increase in $\mathrm{VO}_{2 \max }$ but impaired strength adaptations when compared with
Adaptations to Endurance and Strength Training

strength training alone (Hickson 1980). There is some evidence that concurrent training prevents muscle hypertrophy (Kraemer et al. 1995); however, when the frequency or intensity of concurrent training is decreased below 4 days a week and $70 \%$ of $\mathrm{VO}_{2 \max }$, muscle growth can occur normally. This suggests that something about the volume and/or the intensity of training underlies the concurrent training effect. One suggestion is that the greater training volume and intensity results in a significantly greater caloric deficit and that this decreases the protein synthetic response to feeding (Areta et al. 2014). Examining the caloric cost of training from the Hickson study (Fig. 4) shows that at week 5 of the study, the concurrent training group was expending $\sim 6000 \mathrm{kcal}$ per week compared with $\sim 2000 \mathrm{kcal}$ per week in the strength training alone group, and this differ-

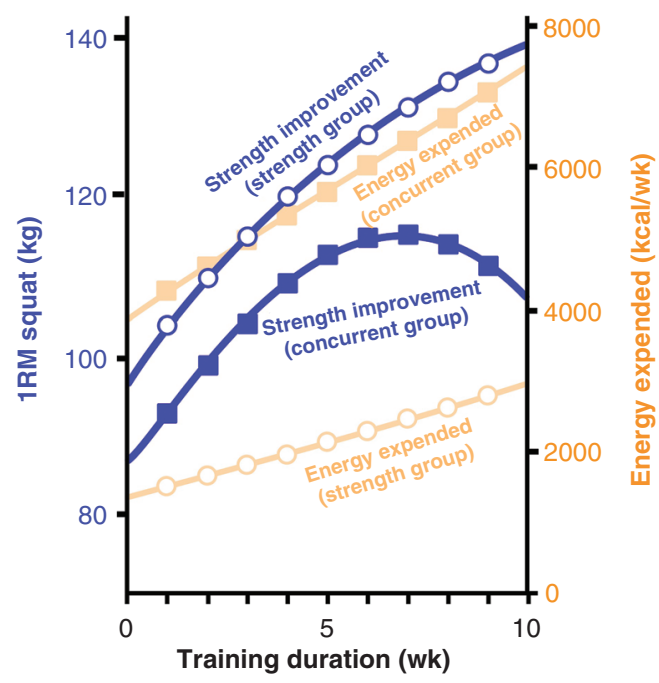

Figure 4. The impact of strength training and concurrent exercise on energy consumption. The classic Hickson (1980) study was the first to observe a decline in strength improvement and strength performance (1RM [repetition maximum] squat) over time with concurrent training (closed blue squares). The decline in strength adaptations occurred once the concurrent group was expending double the kcal/ wk of the strength training only group (open circles). This suggests that the impairment in strength adaptations with concurrent exercise could reflect the role of negative energy balance on muscle hypertrophy. 
D.C. Hughes et al.

ence continued to increase for the last $5 \mathrm{wk}$ of the study. The resulting $4000 \mathrm{kcal}$ per week difference in energy expenditure could easily underlie the difference in muscle size and strength. Another possible explanation for the impaired strength adaptation is that endurance training decreases the neural drive associated with strength training. McCarthy and colleagues (2002) would argue against this hypothesis because they showed that there was no difference in EMG amplitude in men who performed 10 wk of concurrent training compared with those who performed strength training alone. However, it should be noted that these investigators failed to see an effect of concurrent training on the strength adaptation, indicating that the training intensity or volume was not enough to see a concurrent training effect. As with other training modalities, the effect of concurrent training on force transfer has yet to be described. Grosset and colleagues (2009) have suggested that endurance training decreases force transfer; however, whether this could contribute to the concurrent training effect has yet to be determined.

As far as molecular mechanisms, the interaction between the AMP-activated protein kinase (AMPK), which is activated by high-intensity endurance exercise, and mTORC1, which is activated by resistance exercise, has been the major focus of the research. This focus is the result of work in vitro in dividing cells that shows that AMPK can directly inhibit mTORC1 via three distinct mechanisms (Inoki et al. 2002; Gwinn et al. 2008; Zhang et al. 2014). In agreement with the cell culture data, in rodent models in which animals are treated with the AMPKactivating drug AICAR, the activation of mTORC1 is clearly decreased following resistance exercise (Thomson et al. 1985). However, in human studies, the activation of AMPK by high-intensity endurance exercise has minimal effects on mTORC1 activation following resistance exercise (Apro et al. 2015). The difference between the rodent and human data could reflect the fact that exercise preferentially activates the $\alpha 2$ isoform of AMPK (Lee-Young et al. 2008), whereas AICAR would activate both the $\alpha 1$ and $\alpha 2$ isoforms. Interestingly, the $\alpha 1$ isoform of AMPK is activated to inhibit loadinduced muscle growth in vivo (McGee et al. 2008) and when this protein is knocked out the result is greater load-induced muscle hypertrophy (Mounier et al. 2009). This suggests that the inhibition of mTORC1 as a result of activation of AMPK by endurance exercise is likely not the molecular mechanism underlying the impaired hypertrophy and strength with concurrent training.

\section{GENETICS}

An important aspect to all training adaptations, be they strength or endurance, is genetics (Bouchard et al. 2011). Over the last decade, the literature has begun to detail the role played by heritability and genetic differences (polymorphisms) in training adaptations (Beunen and Thomis 2004; Huygens et al. 2004; Timmons et al. 2010; Bouchard et al. 2011; Hughes et al. 2011). Numerous studies have highlighted the diversity of responses to endurance (Timmons et al. 2010) or strength-training programs (Petrella et al. 2008; Erskine et al. 2010) in humans and in rats (Koch et al. 2013), often classifying individuals as nonresponders or extreme responders based on the muscle phenotypes measured (Petrella et al. 2008; Timmons et al. 2010; Davidsen et al. 2011; Thalacker-Mercer et al. 2013; Churchward-Venne et al. 2015; Stec et al. 2016). However, Churchward-Venne and colleagues (2015) have challenged the idea of nonresponders to resistance exercise. In a retrospective analysis of a resistance-type exercise program in older men and women, these investigators reported that, even though a large heterogeneity in the adaptive responses existed, all of the individuals displayed the capacity to adapt with resistance-type exercise training. A similar challenge has recently been raised for endurance exercise, suggesting that nonresponders who exercised harder were able to show some adaptation (Montero and Lundby 2017). Although the existence of true nonresponders remains controversial, the extent of strength and endurance adaptations that occur through training does vary widely (Petrella et al. 2008; Thalacker-Mercer et al. 2013; Stec et al. 
2016) based on messenger RNA (mRNA) and microRNA profiles and translational capacity (Timmons et al. 2010; Davidsen et al. 2011; Phillips et al. 2013; Thalacker-Mercer et al. 2013; Stec et al. 2016). Further, the fact that rats and mice can be bred for more or less improvement in running capacity indicates that there are clearly genes that are determining our response to training (Koch et al. 2013). Once we better understand the variability in adaptations, we may be able to use this information to determine the optimal training program for a given individual. However, these advancements will heavily depend on the usage of large cohorts through collaborative initiatives such as the Molecular Transducers of Physical Activity in Humans National Institutes of Health consortium (commonfund.nih.gov/ MolecularTransducers).

\section{SUMMARY}

The effect of exercise training on muscle phenotype has been appreciated for millennia. In general, individuals who train by exercising for a long time will develop better oxygen delivery to muscle and endurance capacity, whereas those who work against a heavy load will get bigger and stronger muscles. However, recent work using high-intensity short-duration interval training to increase endurance and low-load resistance training to failure to increase muscle size and strength have challenged the classical view of training specificity. For us to truly understand and predict the adaptation that will result from a given exercise, we need to better understand the molecular mechanisms that underlie the change in muscle phenotype with training. Our progress in this area has been slow because of the inherent bias toward signaling molecules that have already been identified. To take the next step forward, we need to assess the molecular events that are initiated after different types of exercise (following acclimatization) that result in similar muscular adaptations in an unbiased manner. When we have identified potential candidate molecules, we will then need to understand how these events interact with our response to feeding because, in the end, a combination of exercise and nutrition are required for the changes that we see in muscle phenotype with training.

\section{REFERENCES}

Aagaard P, Andersen JL. 2010. Effects of strength training on endurance capacity in top-level endurance athletes. Scand J Med Sci Sports 20: 39-47.

Aagaard P, Simonsen EB, Andersen JL, Magnusson P, DyhrePoulsen P. 2002. Increased rate of force development and neural drive of human skeletal muscle following resistance training. J Appl Physiol (1985) 93: 1318-1326.

Aagaard P, Magnusson PS, Larsson B, Kjær M, Krustrup P. 2007. Mechanical muscle function, morphology, and fiber type in lifelong trained elderly. Med Sci Sports Exerc 39: 1989-1996.

Aagaard P, Andersen J, Bennekou M, Larsson B, Olesen J, Crameri R, Magnusson SP, Kjaer M. 2011. Effects of resistance training on endurance capacity and muscle fiber composition in young top-level cyclists. Scand J Med Sci Sports 21: e298-e307.

Albracht K, Arampatzis A. 2013. Exercise-induced changes in triceps surae tendon stiffness and muscle strength af fect running economy in humans. Eur J Appl Physiol 113: $1605-1615$.

Allison SJ, Bailey DM, Folland JP. 2008. Prolonged static stretching does not influence running economy despite changes in neuromuscular function. J Sports Sci 26: 1489-1495.

Andersen LL, Aagaard P. 2006. Influence of maximal muscle strength and intrinsic muscle contractile properties on contractile rate of force development. Eur J Appl Physiol 96: $46-52$.

Apro W, Moberg M, Hamilton DL, Ekblom B, van Hall G, Holmberg HC, Blomstrand E. 2015. Resistance exerciseinduced S6K1 kinase activity is not inhibited in human skeletal muscle despite prior activation of AMPK by high-intensity interval cycling. Am J Physiol Endocrinol Metab 308: E470-E481.

Arampatzis A, De Monte G, Karamanidis K, Morey-Klapsing G, Stafilidis S, Brüggemann GP. 2006. Influence of the muscle-tendon unit's mechanical and morphological properties on running economy. J Exp Biol 209: 33453357.

Areta JL, Burke LM, Camera DM, West DW, Crawshay S, Moore DR, Stellingwerff T, Phillips SM, Hawley JA, Coffey VG. 2014. Reduced resting skeletal muscle protein synthesis is rescued by resistance exercise and protein ingestion following short-term energy deficit. Am J Physiol Endocrinol Metab 306: E989-E997.

Baar K, Esser K. 1999. Phosphorylation of p70 $56 \mathrm{k}$ correlates with increased skeletal muscle mass following resistance exercise. Am J Physiol Cell Physiol 276: C120-C127.

Baar K, Wende AR, Jones TE, Marison M, Nolte LA, Chen M, Kelly DP, Holloszy JO. 2002. Adaptations of skeletal muscle to exercise: Rapid increase in the transcriptional coactivator PGC-1. FASEB J 16: 1879-1886.

Baker SJ, Fearon ER, Nigro JM, Hamilton SR, Preisinger AC, Jessup JM, vanTuinen P, Ledbetter DH, Barker DF, Naka- 
D.C. Hughes et al.

mura Y, et al. 1989. Chromosome 17 deletions and p53 gene mutations in colorectal carcinomas. Science 244: 217-221.

Barnes KR, Kilding AE. 2015. Strategies to improve running economy. Sports Med 45: 37-56.

Barnes KR, Mcguigan MR, Kilding AE. 2014. Lower-body determinants of running economy in male and female distance runners. J Strength Cond Res 28: 1289-1297.

Bartlett JD, Joo CH, Jeong TS, Louhelainen J, Cochran AJ, Gibala MJ, Gregson W, Close GL, Drust B, Morton JP. 2012. Matched work high-intensity interval and continuous running induce similar increases in PGC- $1 \alpha$ mRNA, AMPK, p38, and p53 phosphorylation in human skeletal muscle. J Appl Physiol (1985) 112: 1135-1143.

Bartlett JD, Louhelainen J, Iqbal Z, Cochran AJ, Gibala MJ, Gregson W, Close GL, Drust B, Morton JP. 2013. Reduced carbohydrate availability enhances exercise-induced p53 signaling in human skeletal muscle: Implications for mitochondrial biogenesis. Am J Physiol Regul Integr Comp Physiol 304: R450-R458.

Bartlett JD, Close GL, Drust B, Morton JP. 2014. The emerging role of p53 in exercise metabolism. Sports Med 44: 303-309.

Beattie K, Kenny IC, Lyons M, Carson BP. 2014. The effect of strength training on performance in endurance athletes. Sports Med 44: 845-865.

Beunen G, Thomis M. 2004. Gene powered? Where to go from heritability $\left(h^{2}\right)$ in muscle strength and power? Exerc Sport Sci Rev 32: 148-154.

Bishop DJ, Granata C, Eynon N. 2014. Can we optimise the exercise training prescription to maximise improvements in mitochondria function and content? Biochim Biophys Acta 1840: 1266-1275.

Boppart MD, Burkin DJ, Kaufman SJ. 2006. $\alpha 7 \beta 1$-integrin regulates mechanotransduction and prevents skeletal muscle injury. Am J Physiol Cell Physiol 290: C1660C1665.

Bouchard C, Rankinen T, Timmons JA. 2011. Genomics and genetics in the biology of adaptation to exercise. Compr Physiol 1: 1603-1648.

Brook MS, Wilkinson DJ, Mitchell WK, Lund JN, Szewczyk NJ, Greenhaff PL, Smith K, Atherton PJ. 2015. Skeletal muscle hypertrophy adaptations predominate in the early stages of resistance exercise training, matching deuterium oxide-derived measures of muscle protein synthesis and mechanistic target of rapamycin complex 1 signaling. FASEB J 29: 4485-4496.

Brooks GA. 2012. Bioenergetics of exercising humans. Compr Physiol 2: 537-562.

Carroll TJ, Herbert RD, Munn J, Lee M, Gandevia SC. 2006. Contralateral effects of unilateral strength training: Evidence and possible mechanisms. J Appl Physiol (1985) 101: 1514-1522.

Cartee GD, Hepple RT, Bamman MM, Zierath JR. 2016. Exercise promotes healthy aging of skeletal muscle. Cell Metab 23: 1034-1047.

Chapman AR, Vicenzino B, Blanch P, Hodges PW. 2008. Patterns of leg muscle recruitment vary between novice and highly trained cyclists. J Electromyogr Kinesiol 18: 359-371.
Churchward-Venne TA, Tieland M, Verdijk LB, Leenders M, Dirks ML, de Groot LC, van Loon LJ. 2015. There are no nonresponders to resistance-type exercise training in older men and women. J Am Med Dir Assoc 16: 400-411.

Cochran AJ, Percival ME, Tricarico S, Little JP, Cermak N, Gillen JB, Tarnopolsky MA, Gibala MJ. 2014. Intermittent and continuous high-intensity exercise training induce similar acute but different chronic muscle adaptations. Exp Physiol 99: 782-791.

Counts BR, Buckner SL, Dankel SJ, Jessee MB, Mattocks KT, Mouser JG, Laurentino GC, Loenneke JP. 2016. The acute and chronic effects of "NO LOAD" resistance training. Physiol Behav 164: 345-352.

Coyle EF. 1995. Integration of the physiological factors determining endurance performance ability. Exerc Sport Sci Rev 23: 25-64.

Coyle E, Hagberg J, Hurley B, Martin W, Ehsani A, Holloszy J. 1983. Carbohydrate feeding during prolonged strenuous exercise can delay fatigue. J Appl Physiol (1985) 55: 230-235.

Coyle EF, Coggan AR, Hemmert M, Ivy JL. 1986. Muscle glycogen utilization during prolonged strenuous exercise when fed carbohydrate. J Appl Physiol (1985) 61: 165172.

Coyle EF, Coggan AR, Hopper M, Walters TJ. 1988. Determinants of endurance in well-trained cyclists. J Appl Physiol (1985) 64: 2622-2630.

Craib MW, Mitchell VA, Fields KB, Cooper TR, Hopewell R, Morgan DW. 1996. The association between flexibility and running economy in sub-elite male distance runners. Med Sci Sports Exerc 28: 737-743.

Cui G, Park S, Badeaux AI, Kim D, Lee J, Thompson JR, Yan F, Kaneko S, Yuan Z, Botuyan MV. 2012. PHF20 is an effector protein of p53 double lysine methylation that stabilizes and activates p53. Nat Struct Mol Biol 19: 916-924.

Cureton KJ, Collins MA, Hill DW, McElhannon FM Jr. 1988. Muscle hypertrophy in men and women. Med Sci Sports Exerc 20: 338-344.

Damas F, Phillips SM, Lixandrao ME, Vechin FC, Libardi CA, Roschel H, Tricoli V, Ugrinowitsch C. 2016. Early resistance training-induced increases in muscle crosssectional area are concomitant with edema-induced muscle swelling. Eur J Appl Physiol 116: 49-56.

Daussin FN, Zoll J, Ponsot E, Dufour SP, Doutreleau S, Lonsdorfer E, Ventura-Clapier R, Mettauer B, Piquard F, Geny B. 2008. Training at high exercise intensity promotes qualitative adaptations of mitochondrial function in human skeletal muscle. J Appl Physiol (1985) 104: 1436-1441.

Davidsen PK, Gallagher IJ, Hartman JW, Tarnopolsky MA, Dela F, Helge JW, Timmons JA, Phillips SM. 2011. High responders to resistance exercise training demonstrate differential regulation of skeletal muscle microRNA expression. J Appl Physiol (1985) 110: 309-317.

DeFreitas JM, Beck TW, Stock MS, Dillon MA, Kasishke PR II. 2011. An examination of the time course of traininginduced skeletal muscle hypertrophy. Eur J Appl Physiol 111: 2785-2790.

Di Donato DM, West DW, Churchward-Venne TA, Breen L, Baker SK, Phillips SM. 2014. Influence of aerobic exercise intensity on myofibrillar and mitochondrial protein syn- 
thesis in young men during early and late postexercise recovery. Am J Physiol Endocrinol Metab 306: E1025E1032.

Durham WJ, Casperson SL, Dillon EL, Keske MA, PaddonJones D, Sanford AP, Hickner RC, Grady JJ, SheffieldMoore M. 2010. Age-related anabolic resistance after endurance-type exercise in healthy humans. FASEB J 24: 4117-4127.

Edgett BA, Fortner ML, Bonen A, Gurd BJ. 2013. Mammalian target of rapamycin pathway is up-regulated by both acute endurance exercise and chronic muscle contraction in rat skeletal muscle. Appl Physiol Nutr Metab 38: $862-$ 869.

Egan B, Zierath JR. 2013. Exercise metabolism and the molecular regulation of skeletal muscle adaptation. Cell Metab 17: 162-184.

Enoka RM. 1988. Muscle strength and its development. Sports Med 6: 146-168.

Erskine RM, Jones DA, Williams AG, Stewart CE, Degens H. 2010. Inter-individual variability in the adaptation of human muscle specific tension to progressive resistance training. Eur J Appl Physiol 110: 1117-1125.

Favier R, Constable S, Chen M, Holloszy J. 1986. Endurance exercise training reduces lactate production. J Appl Physiol (1985) 61: 885-889.

Fletcher JR, Esau SP, MacIntosh BR. 2010. Changes in tendon stiffness and running economy in highly trained distance runners. Eur J Appl Physiol 110: 1037-1046.

Folland JP, Williams AG. 2007. Morphological and neurological contributions to increased strength. Sports Med 37: 145-168.

Frontera WR, Meredith CN, O'Reilly KP, Knuttgen HG, Evans WJ. 1988. Strength conditioning in older men: Skeletal muscle hypertrophy and improved function. $J$ Appl Physiol (1985) 64: 1038-1044.

Fry AC. 2004. The role of resistance exercise intensity on muscle fibre adaptations. Sports Med 34: 663-679.

Gibala MJ, McGee SL. 2008. Metabolic adaptations to shortterm high-intensity interval training: A little pain for a lot of gain? Exerc Sport Sci Rev 36: 58-63.

Gibala MJ, Little JP, Van Essen M, Wilkin GP, Burgomaster KA, Safdar A, Raha S, Tarnopolsky MA. 2006. Short-term sprint interval versus traditional endurance training: Similar initial adaptations in human skeletal muscle and exercise performance. J Physiol 575: 901-911.

Gibala MJ, McGee SL, Garnham AP, Howlett KF, Snow RJ, Hargreaves M. 2009. Brief intense interval exercise activates AMPK and p38 MAPK signaling and increases the expression of PGC-1 $\alpha$ in human skeletal muscle. J Appl Physiol (1985) 106: 929-934.

Gibala MJ, Gillen JB, Percival ME. 2014. Physiological and health-related adaptations to low-volume interval training: Influences of nutrition and sex. Sports Med 44: S127-S137.

Gillen JB, Gibala MJ. 2013. Is high-intensity interval training a time-efficient exercise strategy to improve health and fitness? Appl Physiol Nutr Metab 39: 409-412.

Goodpaster BH, Park SW, Harris TB, Kritchevsky SB, Nevitt M, Schwartz AV, Simonsick EM, Tylavsky FA, Visser M, Newman AB. 2006. The loss of skeletal muscle strength, mass, and quality in older adults: The health, aging and body composition study. J Gerontol A Biol Sci Med Sci 61: 1059-1064.

Granata C, Oliveira RS, Little JP, Renner K, Bishop DJ. 2016a. Mitochondrial adaptations to high-volume exercise training are rapidly reversed after a reduction in training volume in human skeletal muscle. FASEB J 30: 3413-3423.

Granata C, Oliveira RS, Little JP, Renner K, Bishop DJ. 2016b. Training intensity modulates changes in PGC$1 \alpha$ and p53 protein content and mitochondrial respiration, but not markers of mitochondrial content in human skeletal muscle. FASEB J 30: 959-970.

Grosset JF, Piscione J, Lambertz D, Pérot C. 2009. Paired changes in electromechanical delay and musculo-tendinous stiffness after endurance or plyometric training. Eur J Appl Physiol 105: 131-139.

Gwinn DM, Shackelford DB, Egan DF, Mihaylova MM, Mery A, Vasquez DS, Turk BE, Shaw RJ. 2008. AMPK phosphorylation of raptor mediates a metabolic checkpoint. Mol Cell 30: 214-226.

Häkkinen K, Pakarinen A. 1993. Acute hormonal responses to two different fatiguing heavy-resistance protocols in male athletes. J Appl Physiol (1985) 74: 882-887.

Häkkinen K, Kallinen M, Izquierdo M, Jokelainen K, Lassila H, Mälkiä E, Kraemer W, Newton R, Alen M. 1998a. Changes in agonist-antagonist EMG, muscle CSA, and force during strength training in middle-aged and older people. J Appl Physiol (1985) 84: 1341-1349.

Häkkinen K, Newton RU, Gordon SE, McCormick M, Volek JS, Nindl BC, Gotshalk LA, Campbell WW, Evans WJ, Häkkinen A. 1998b. Changes in muscle morphology, electromyographic activity, and force production characteristics during progressive strength training in young and older men. J Gerontol A Biol Sci Med Sci 53: B415B423.

Harber MP, Crane JD, Dickinson JM, Jemiolo B, Raue U, Trappe TA, Trappe SW. 2009a. Protein synthesis and the expression of growth-related genes are altered by running in human vastus lateralis and soleus muscles. Am J Physiol Regul Integr Comp Physiol 296: R708-R714.

Harber MP, Konopka AR, Douglass MD, Minchev K, Kaminsky LA, Trappe TA, Trappe S. 2009b. Aerobic exercise training improves whole muscle and single myofiber size and function in older women. Am J Physiol Regul Integr Comp Physiol 297: R1452-R1459.

Harber MP, Konopka AR, Jemiolo B, Trappe SW, Trappe TA, Reidy PT. 2010. Muscle protein synthesis and gene expression during recovery from aerobic exercise in the fasted and fed states. Am J Physiol Regul Integr Comp Physiol 299: R1254-R1262.

Harber MP, Konopka AR, Undem MK, Hinkley JM, Minchev K, Kaminsky LA, Trappe TA, Trappe S. 2012. Aerobic exercise training induces skeletal muscle hypertrophy and age-dependent adaptations in myofiber function in young and older men. J Appl Physiol (1985) 113: $1495-$ 1504.

Heise G, Shinohara M, Binks L. 2008. Biarticular leg muscles and links to running economy. Int J Sports Med 29: 688691.

Herzog W, Schappacher G, DuVall M, Leonard TR, Herzog JA. 2016. Residual force enhancement following eccentric 
D.C. Hughes et al.

contractions: A new mechanism involving titin. Physiology 31: 300-312.

Hickson RC. 1980. Interference of strength development by simultaneously training for strength and endurance. Eur J Appl Physiol Occup Physiol 45: 255-263.

Holloszy JO. 1967. Biochemical adaptations in muscle effects of exercise on mitochondrial oxygen uptake and respiratory enzyme activity in skeletal muscle. J Biol Chem 242: 2278-2282.

Holloszy JO, Coyle EF. 1984. Adaptations of skeletal muscle to endurance exercise and their metabolic consequences. J Appl Physiol (1985) 56: 831-838.

Houston M, Froese E, Valeriote SP, Green HJ, Ranney DA. 1983. Muscle performance, morphology and metabolic capacity during strength training and detraining: A one leg model. Eur J Appl Physiol Occup Physiol 51: 25-35.

Hughes DC, Day SH, Ahmetov II, Williams AG. 2011. Genetics of muscle strength and power: Polygenic profile similarity limits skeletal muscle performance. J Sports Sci 29: $1425-1434$.

Hughes DC, Wallace MA, Baar K. 2015. Effects of aging, exercise, and disease on force transfer in skeletal muscle. Am J Physiol Endocrinol Metab 309: E1-E10.

Hughes DC, Marcotte GR, Marshall AG, West DW, Baehr LM, Wallace MA, Saleh PM, Bodine SC, Baar K. 2016 Age-related differences in dystrophin: Impact on force transfer proteins, membrane integrity, and neuromuscular junction stability. J Gerontol A Biol Sci Med Sci doi: 10.1093/gerona/glw109.

Huygens W, Thomis MA, Peeters MW, Vlietinck RF, Beunen GP. 2004. Determinants and upper-limit heritabilities of skeletal muscle mass and strength. Can J Appl Physiol 29: $186-200$.

Inoki K, Li Y, Zhu T, Wu J, Guan KL. 2002. TSC2 is phosphorylated and inhibited by Akt and suppresses mTOR signalling. Nat Cell Biol 4: 648-657.

Jacobs BL, You JS, Frey JW, Goodman CA, Gundermann DM, Hornberger TA. 2013a. Eccentric contractions increase the phosphorylation of tuberous sclerosis complex-2 (TSC2) and alter the targeting of TSC2 and the mechanistic target of rapamycin to the lysosome. J Physiol 591: 4611-4620.

Jacobs RA, Flück D, Bonne TC, Bürgi S, Christensen PM, Toigo M, Lundby C. 2013b. Improvements in exercise performance with high-intensity interval training coincide with an increase in skeletal muscle mitochondrial content and function. J Appl Physiol (1985) 115: 785793.

Jones D, Rutherford O, Parker D. 1989. Physiological changes in skeletal muscle as a result of strength training. Q J Exp Physiol 74: 233-256.

Jones TW, Howatson G, Russell M, French DN. 2013. Performance and neuromuscular adaptations following differing ratios of concurrent strength and endurance training. J Strength Cond Res 27: 3342-3351.

Joyner MJ, Coyle EF. 2008. Endurance exercise performance: The physiology of champions. J Physiol 586: 35-44.

Kidgell DJ, Frazer AK, Rantalainen T, Ruotsalainen I, Ahtiainen J, Avela J, Howatson G. 2015. Increased crosseducation of muscle strength and reduced corticospinal inhibition following eccentric strength training. Neuroscience 300: 566-575.

Knuttgen HG, Kraemer WJ. 1987. Terminology and measurement in exercise performance. J Strength Cond Res 1: $1-10$.

Koch LG, Pollott GE, Britton SL. 2013. Selectively bred rat model system for low and high response to exercise training. Physiol Genomics 45: 606-614.

Konopka AR, Harber MP. 2014. Skeletal muscle hypertrophy after aerobic exercise training. Exerc Sport Sci Rev 42: 53-61.

Konopka AR, Douglass MD, Kaminsky LA, Jemiolo B, Trappe TA, Trappe S, Harber MP. 2010. Molecular adaptations to aerobic exercise training in skeletal muscle of older women. J Gerontol A Biol Sci Med Sci 65: 12011207.

Korhonen MT, Cristea A, Alén M, Häkkinen K, Sipilä S, Mero A, Viitasalo JT, Larsson L, Suominen H. 2006. Aging, muscle fiber type, and contractile function in sprinttrained athletes. J Appl Physiol (1985) 101: 906-917.

Kosek DJ, Bamman MM. 2008. Modulation of the dystrophin-associated protein complex in response to resistance training in young and older men. J Appl Physiol (1985) 104: 1476-1484.

Kraemer WJ, Gordon S, Fleck S, Marchitelli L, Mello R, Dziados J, Friedl K, Harman E, Maresh C, Fry A. 1991. Endogenous anabolic hormonal and growth factor responses to heavy resistance exercise in males and females. Int J Sports Med 12: 228-235.

Kraemer WJ, Patton JF, Gordon SE, Harman EA, Deschenes MR, Reynolds K, Newton RU, Triplett NT, Dziados JE 1995. Compatibility of high-intensity strength and endurance training on hormonal and skeletal muscle adaptations. J Appl Physiol (1985) 78: 976-989.

Latella C, Kidgell DJ, Pearce AJ. 2012. Reduction in corticospinal inhibition in the trained and untrained limb following unilateral leg strength training. Eur J Appl Physiol 112: 3097-3107.

Laursen PB, Jenkins DG. 2002. The scientific basis for highintensity interval training. Sports Med 32: 53-73.

Lee-Young RS, Koufogiannis G, Canny BJ, McConell GK. 2008. Acute exercise does not cause sustained elevations in AMPK signaling or expression. Med Sci Sports Exerc 40: 1490-1494.

Lehti TM, Kalliokoski R, Komulainen J. 2007. Repeated bout effect on the cytoskeletal proteins titin, desmin, and dystrophin in rat skeletal muscle. J Muscle Res Cell Motil 28: 39-47.

Levine A, Hu W, Feng Z. 2006. The P53 pathway: What questions remain to be explored? Cell Death Differ 13: 1027-1036.

Little JP, Safdar A, Cermak N, Tarnopolsky MA, Gibala MJ. 2010a. Acute endurance exercise increases the nuclear abundance of PGC-1 $\alpha$ in trained human skeletal muscle. Am J Physiol Regul Integr Comp Physiol 298: R912-R917.

Little JP, Safdar A, Wilkin GP, Tarnopolsky MA, Gibala MJ. 2010b. A practical model of low-volume high-intensity interval training induces mitochondrial biogenesis in human skeletal muscle: Potential mechanisms. J Physiol 588: 1011-1022. 
Little JP, Safdar A, Bishop D, Tarnopolsky MA, Gibala MJ. 2011. An acute bout of high-intensity interval training increases the nuclear abundance of PGC- $1 \alpha$ and activates mitochondrial biogenesis in human skeletal muscle. Am J Physiol Regul Integr Comp Physiol 300: R1303-R1310.

Lovering RM, De Deyne PG. 2004. Contractile function, sarcolemma integrity, and the loss of dystrophin after skeletal muscle eccentric contraction-induced injury. Am J Physiol Cell Physiol 286: C230-C238.

Macaluso F, Isaacs AW, Di Felice V, Myburgh KH. 2014 Acute change of titin at mid-sarcomere remains despite 8 wk of plyometric training. J Appl Physiol (1985) 116: 1512-1519.

MacInnis MJ, Zacharewicz E, Martin BJ, Haikalis ME, Skelly LE, Tarnopolsky MA, Murphy RM, Gibala MJ. 2016. Superior mitochondrial adaptations in human skeletal muscle after interval compared to continuous single-leg cycling matched for total work. J Physiol doi: 10.1113/ JP272570.

Maffiuletti NA, Aagaard P, Blazevich AJ, Folland J, Tillin N, Duchateau J. 2016. Rate of force development: Physiological and methodological considerations. Eur J Appl Physiol 116: 1091-1116.

Mascher H, Ekblom B, Rooyackers O, Blomstrand E. 2011. Enhanced rates of muscle protein synthesis and elevated mTOR signalling following endurance exercise in human subjects. Acta Physiol (Oxf) 202: 175-184.

Matoba S, Kang JG, Patino WD, Wragg A, Boehm M, Gavrilova O, Hurley PJ, Bunz F, Hwang PM. 2006. p53 regulates mitochondrial respiration. Science 312: 1650-1653.

McBride JM, Triplett-McBride T, Davie AJ, Abernethy PJ, Newton RU. 2003. Characteristics of titin in strength and power athletes. Eur J Appl Physiol 88: 553-557.

McCall GE, Byrnes WC, Fleck SJ, Dickinson A, Kraemer WJ. 1999. Acute and chronic hormonal responses to resistance training designed to promote muscle hypertrophy. Can J Appl Physiol 24: 96-107.

McCarthy JP, Pozniak MA, Agre JC. 2002. Neuromuscular adaptations to concurrent strength and endurance training. Med Sci Sports Exerc 34: 511-519.

McGee SL, Mustard KJ, Hardie DG, Baar K. 2008. Normal hypertrophy accompanied by phosphoryation and activation of AMP-activated protein kinase $\alpha 1$ following overload in LKB1 knockout mice. J Physiol 586: 17311741.

McGregor RA, Cameron-Smith D, Poppitt SD. 2014. It is not just muscle mass: A review of muscle quality, composition and metabolism during ageing as determinants of muscle function and mobility in later life. Longev Healthspan 3: 9.

McGuigan MR, Sharman MJ, Newton RU, Davie AJ, Murphy AJ, McBride JM. 2003. Effect of explosive resistance training on titin and myosin heavy chain isoforms in trained subjects. J Strength Cond Res 17: 645-651.

Mebes C, Amstutz A, Luder G, Ziswiler HR, Stettler M, Villiger PM, Radlinger L. 2008. Isometric rate of force development, maximum voluntary contraction, and balance in women with and without joint hypermobility. Arthritis Rheum 59: 1665-1669.

Mero A, Hulmi J, Salmijärvi H, Katajavuori M, Haverinen M, Holviala J, Ridanpää T, Häkkinen K, Kovanen V, Ahtiainen J. 2013. Resistance training induced increase in muscle fiber size in young and older men. Eur J Appl Physiol 113: 641-650.

Mitchell CJ, Churchward-Venne TA, West DW, Burd NA, Breen L, Baker SK, Phillips SM. 2012. Resistance exercise load does not determine training-mediated hypertrophic gains in young men. J Appl Physiol (1985) 113: 71-77.

Montero D, Lundby C. 2017. Refuting the myth of nonresponse to exercise training: "Non-responders" do respond to higher dose of training. J Physiol doi: 10.1113/ JP273480.

Morton RW, Oikawa SY, Wavell CG, Mazara N, McGlory C, Quadrilatero J, Baechler BL, Baker SK, Phillips SM. 2016. Neither load nor systemic hormones determine resistance training-mediated hypertrophy or strength gains in resistance-trained young men. J Appl Physiol (1985) 121: $129-138$.

Mounier R, Lantier L, Leclerc J, Sotiropoulos A, Pende M, Daegelen D, Sakamoto K, Foretz M, Viollet B. 2009. Important role for AMPK $\alpha 1$ in limiting skeletal muscle cell hypertrophy. FASEB J 23: 2264-2273.

Munn J, Herbert RD, Gandevia SC. 2004. Contralateral effects of unilateral resistance training: A meta-analysis. $J$ Appl Physiol (1985) 96: 1861-1866.

Munn J, Herbert RD, Hancock MJ, Gandevia SC. 2005. Training with unilateral resistance exercise increases contralateral strength. J Appl Physiol (1985) 99: 1880-1884.

Narici MV, Roi G, Landoni L, Minetti A, Cerretelli P. 1989. Changes in force, cross-sectional area and neural activation during strength training and detraining of the human quadriceps. Eur J Appl Physiol Occup Physiol 59: 310-319.

Nelson A, Kokkonen J, Eldredge C, Cornwell A, GlickmanWeiss E. 2001. Chronic stretching and running economy. Scand J Med Sci Sports 11: 260-265.

Newman AB, Kupelian V, Visser M, Simonsick EM, Goodpaster BH, Kritchevsky SB, Tylavsky FA, Rubin SM, Harris TB. 2006. Strength, but not muscle mass, is associated with mortality in the health, aging and body composition study cohort. J Gerontol A Biol Sci Med Sci 61: 72-77.

Nigro JM, Baker SJ, Preisinger AC, Jessup JM, Hostetter R, Cleary K, Bigner SH, Davidson N, Baylin S, Devilee P, et al. 1989. Mutations in the p53 gene occur in diverse human tumour types. Nature 342: 705-708.

Ogasawara R, Loenneke JP, Thiebaud RS, Abe T. 2013. Lowload bench press training to fatigue results in muscle hypertrophy similar to high-load bench press training. Int J Clin Med 4: 114.

Ottenheijm CA, Granzier H, Labeit S. 2012. The sarcomeric protein nebulin: Another multifunctional giant in charge of muscle strength optimization. Front Physiol 3: 37.

Paavolainen L, Häkkinen K, Hämäläinen I, Nummela A, Rusko H. 1999a. Explosive-strength training improves $5-\mathrm{km}$ running time by improving running economy and muscle power. J Appl Physiol (1985) 86: 1527-1533.

Paavolainen L, Nummela A, Rusko H, Häkkinen K. 1999 b. Neuromuscular characteristics and fatigue during $10 \mathrm{~km}$ running. Int J Sports Med 20: 516-521.

Paavolainen LM, Nummela A, Rusko HK. 1999c. Neuromuscular characteristics and muscle power as determinants of 5-km running performance. Med Sci Sports Exerc 31: 124-130. 
D.C. Hughes et al.

Palmisano MG, Bremner SN, Hornberger TA, Meyer GA, Domenighetti AA, Shah SB, Kiss B, Kellermayer M, Ryan AF, Lieber RL. 2015. Skeletal muscle intermediate filaments form a stress-transmitting and stress-signaling network. J Cell Sci 128: 219-224.

Parcell AC, Woolstenhulme MT, Sawyer RD. 2009. Structural protein alterations to resistance and endurance cycling exercise training. J Strength Cond Res 23: 359-365.

Park JY, Wang Py, Matsumoto T, Sung HJ, Ma W, Choi JW Anderson SA, Leary SC, Balaban RS, Kang JG. 2009. p53 improves aerobic exercise capacity and augments skeletal muscle mitochondrial DNA content. Circ Res 105: 705712.

Park S, Kim D, Dan HC, Chen H, Testa JR, Cheng JQ. 2012. Identification of Akt interaction protein PHF20/TZP that transcriptionally regulates p53. J Biol Chem 287: 11151-11163.

Petrella JK, Kim Js, Mayhew DL, Cross JM, Bamman MM. 2008. Potent myofiber hypertrophy during resistance training in humans is associated with satellite cell-mediated myonuclear addition: A cluster analysis. J Appl Physiol (1985) 104: 1736-1742.

Phillips BE, Williams JP, Gustafsson T, Bouchard C, Rankinen T, Knudsen S, Smith K, Timmons JA, Atherton PJ. 2013. Molecular networks of human muscle adaptation to exercise and age. PLoS Genet 9: e1003389.

Philp A, Schenk S, Perez-Schindler J, Hamilton DL, Breen L, Laverone E, Jeromson S, Phillips SM, Baar K. 2015. Rapamycin does not prevent increases in myofibrillar or mitochondrial protein synthesis following endurance exercise. J Physiol 593: 4275-4284.

Pilegaard H, Saltin B, Neufer PD. 2003. Exercise induces transient transcriptional activation of the PGC- $1 \alpha$ gene in human skeletal muscle. J Physiol 546: 851-858.

Powers K, Nishikawa K, Joumaa V, Herzog W. 2016. Decreased force enhancement in skeletal muscle sarcomere with a deletion in titin. J Exp Biol 219: 1311-1316.

Pyka G, Lindenberger E, Charette S, Marcus R. 1994. Muscle strength and fiber adaptations to a year-long resistance training program in elderly men and women. $J$ Gerontol 49: M22-M27.

Ramaswamy KS, Palmer ML, van der Meulen JH, Renoux A, Kostrominova TY, Michele DE, Faulkner JA. 2011. Lateral transmission of force is impaired in skeletal muscles of dystrophic mice and very old rats. J Physiol 589: 11951208.

Rønnestad BR, Hansen EA, Raastad T. 2010. In-season strength maintenance training increases well-trained cyclists' performance. Eur J Appl Physiol 110: 1269-1282.

Rønnestad BR, Hansen EA, Raastad T. 2011. Strength training improves 5-min all-out performance following 185 min of cycling. Scand J Med Sci Sports 21: 250-259.

Rønnestad BR, Hansen EA, Raastad T. 2012. High volume of endurance training impairs adaptations to 12 weeks of strength training in well-trained endurance athletes. Eur J Appl Physiol 112: 1457-1466.

Sale DG. 1988. Neural adaptation to resistance training. Med Sci Sports Exerc 20: S135-S145.

Saleem A, Hood DA. 2013. Acute exercise induces tumour suppressor protein p53 translocation to the mitochon- dria and promotes a p53-Tfam-mitochondrial DNA complex in skeletal muscle. J Physiol 591: 3625-3636.

Saleem A, Adhihetty PJ, Hood DA. 2009. Role of p53 in mitochondrial biogenesis and apoptosis in skeletal muscle. Physiol Genomics 37: 58-66.

Saunders PU, Pyne DB, Telford RD, Hawley JA. 2004. Factors affecting running economy in trained distance runners. Sports Med 34: 465-485.

Schoenfeld BJ, Peterson MD, Ogborn D, Contreras B, Sonmez GT. 2015. Effects of low-vs. high-load resistance training on muscle strength and hypertrophy in welltrained men. J Strength Cond Res 29: 2954-2963.

Schroeder ET, Villanueva M, West D, Phillips SM. 2013. Are acute post-resistance exercise increases in testosterone, growth hormone, and IGF-1 necessary to stimulate skeletal muscle anabolism and hypertrophy? Med Sci Sports Exerc 45: 2044-2051.

Scripture E, Smith TL, Brown EM. 1894. On the education of muscular control and power. Stud Yale Psychol Lab 2: $114-119$.

Serpiello FR, McKenna MJ, Bishop DJ, Aughey RJ, Caldow MK, Cameron-Smith D, Stepto NK. 2012. Repeated sprints alter signaling related to mitochondrial biogenesis in humans. Med Sci Sports Exerc 44: 827-834.

Seynnes OR, de Boer M, Narici MV. 2007. Early skeletal muscle hypertrophy and architectural changes in response to high-intensity resistance training. J Appl Physiol (1985) 102: 368-373.

Short KR, Vittone JL, Bigelow ML, Proctor DN, Nair KS. 2004. Age and aerobic exercise training effects on whole body and muscle protein metabolism. Am J Physiol Endocrinol Metab 286: E92-E101.

Shrier I. 2004. Does stretching improve performance?: A systematic and critical review of the literature. Clin J Sport Med 14: 267-273.

Sleivert GG, Wenger HA. 1994. Reliability of measuring isometric and isokinetic peak torque, rate of torque development, integrated electromyography, and tibial nerve conduction velocity. Arch Phys Med Rehabil 75: 13151321.

Staron R, Malicky E, Leonardi M, Falkel J, Hagerman F, Dudley G. 1990. Muscle hypertrophy and fast fiber type conversions in heavy resistance-trained women. Eur J Appl Physiol Occup Physiol 60: 71-79.

Staron RS, Leonardi MJ, Karapondo DL, Malicky ES, Falkel JE, Hagerman FC, Hikida RS. 1991. Strength and skeletal muscle adaptations in heavy-resistance-trained women after detraining and retraining. J Appl Physiol (1985) 70: 631-640.

Staron R, Karapondo D, Kraemer W, Fry A, Gordon S, Falkel J, Hagerman F, Hikida R. 1994. Skeletal muscle adaptations during early phase of heavy-resistance training in men and women. J Appl Physiol (1985) 76: 1247-1255.

Stec MJ, Kelly NA, Many GM, Windham ST, Tuggle SC, Bamman MM. 2016. Ribosome biogenesis may augment resistance training-induced myofiber hypertrophy and is required for myotube growth in vitro. Am J Physiol Endocrinol Metab 310: E652-E661.

Storen O, Helgerud J, Stoa EM, Hoff J. 2008. Maximal strength training improves running economy in distance runners. Med Sci Sports Exerc 40: 1087. 
Suetta C, Aagaard P, Rosted A, Jakobsen AK, Duus B, Kjaer M, Magnusson SP. 2004. Training-induced changes in muscle CSA, muscle strength, EMG, and rate of force development in elderly subjects after long-term unilateral disuse. J Appl Physiol (1985) 97: 1954-1961.

Sunde A, Støren Ø, Bjerkaas M, Larsen MH, Hoff J, Helgerud J. 2010. Maximal strength training improves cycling economy in competitive cyclists. J Strength Cond Res 24: 2157-2165.

Thalacker-Mercer A, Stec M, Cui X, Cross J, Windham S, Bamman M. 2013. Cluster analysis reveals differential transcript profiles associated with resistance training-induced human skeletal muscle hypertrophy. Physiol Genomics 45: 499-507.

Thomson DM, Fick CA, Gordon SE. 1985. AMPK activation attenuates $\mathrm{S} 6 \mathrm{~K} 1,4 \mathrm{E}-\mathrm{BP} 1$, and eEF2 signaling responses to high-frequency electrically stimulated skeletal muscle contractions. J Appl Physiol (1985) 104: 625-632.

Timmons JA, Knudsen S, Rankinen T, Koch LG, Sarzynski M, Jensen T, Keller P, Scheele C, Vollaard NB, Nielsen S. 2010. Using molecular classification to predict gains in maximal aerobic capacity following endurance exercise training in humans. J Appl Physiol (1985) 108: 14871496.

Trappe TA, Carroll CC, Dickinson JM, LeMoine JK, Haus JM, Sullivan BE, Lee JD, Jemiolo B, Weinheimer EM, Hollon CJ. 2011. Influence of acetaminophen and ibuprofen on skeletal muscle adaptations to resistance exercise in older adults. Am J Physiol Regul Integr Comp Physiol 300: R655-R662.

Trehearn TL, Buresh RJ. 2009. Sit-and-reach flexibility and running economy of men and women collegiate distance runners. J Strength Cond Res 23: 158-162.

Vikmoen O, Ellefsen S, Trøen Ø, Hollan I, Hanestadhaugen M, Raastad T, Rønnestad BR. 2015. Strength training improves cycling performance, fractional utilization of $\mathrm{VO}_{2 \max }$ and cycling economy in female cyclists. Scand $J$ Med Sci Sports 26: 384-396.

Visser M, Goodpaster BH, Kritchevsky SB, Newman AB, Nevitt M, Rubin SM, Simonsick EM, Harris TB. 2005. Muscle mass, muscle strength, and muscle fat infiltration as predictors of incident mobility limitations in wellfunctioning older persons. J Gerontol A Biol Sci Med Sci 60: $324-333$.

Wernbom M, Augustsson J, Thomeé R. 2007. The influence of frequency, intensity, volume and mode of strength
Adaptations to Endurance and Strength Training

training on whole muscle cross-sectional area in humans. Sports Med 37: 225-264.

West DW, Kujbida GW, Moore DR, Atherton P, Burd NA, Padzik JP, De Lisio M, Tang JE, Parise G, Rennie MJ. 2009. Resistance exercise-induced increases in putative anabolic hormones do not enhance muscle protein synthesis or intracellular signalling in young men. J Appl Physiol (1985) 587: 5239-5247.

West DW, Burd NA, Tang JE, Moore DR, Staples AW, Holwerda AM, Baker SK, Phillips SM. 2010. Elevations in ostensibly anabolic hormones with resistance exercise enhance neither training-induced muscle hypertrophy nor strength of the elbow flexors. J Appl Physiol (1985) 108: 60-67.

West DW, Burd NA, Churchward-Venne TA, Camera DM, Mitchell CJ, Baker SK, Hawley JA, Coffey VG, Phillips SM. 2012. Sex-based comparisons of myofibrillar protein synthesis after resistance exercise in the fed state. J Appl Physiol (1985) 112: 1805-1813.

West DWD, Lee-Barthel A, McIntyre T, Shamim B, Lee CA, Baar K. 2015. The exercise-induced biochemical milieu enhances collagen content and tensile strength of engineered ligaments. J Appl Physiol (1985) 593: 4665-4675.

Woolstenhulme MT, Conlee RK, Drummond MJ, Stites AW, Parcell AC. 2006. Temporal response of desmin and dystrophin proteins to progressive resistance exercise in human skeletal muscle. J Appl Physiol (1985) 100: 18761882.

Yamamoto LM, Lopez RM, Klau JF, Casa DJ, Kraemer WJ, Maresh CM. 2008. The effects of resistance training on endurance distance running performance among highly trained runners: A systematic review. J Strength Cond Res 22: 2036-2044.

Yasuda Y, Miyamura M. 1983. Cross transfer effects of muscular training on blood flow in the ipsilateral and contralateral forearms. Eur J Appl Physiol Occup Physiol 51: $321-329$.

Zampieri S, Pietrangelo L, Loefler S, Fruhmann H, Vogelauer M, Burggraf S, Pond A, Grim-Stieger M, Cvecka J, Sedliak M. 2015. Lifelong physical exercise delays ageassociated skeletal muscle decline. J Gerontol A Biol Sci Med Sci 70: 163-173.

Zhang CS, Jiang B, Li M, Zhu M, Peng Y, Zhang YL, Wu YQ, Li TY, Liang Y, Lu Z, et al. 2014. The lysosomal v-ATPaseRagulator complex is a common activator for AMPK and mTORC1, acting as a switch between catabolism and anabolism. Cell Metab 20: 526-540. 


\section{$\&_{\mathrm{CSH}}^{\infty} \&$ Cold Spring Harbor

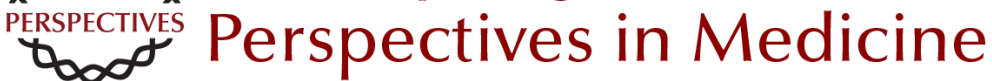

\section{Adaptations to Endurance and Strength Training}

David C. Hughes, Stian Ellefsen and Keith Baar

Cold Spring Harb Perspect Med 2018; doi: 10.1101/cshperspect.a029769 originally published online May 10, 2017

\section{Subject Collection The Biology of Exercise}

Exosomes as Mediators of the Systemic

Adaptations to Endurance Exercise Adeel Safdar and Mark A. Tarnopolsky

Molecular Basis of Exercise-Induced Skeletal

Muscle Mitochondrial Biogenesis: Historical

Advances, Current Knowledge, and Future

Challenges

Christopher G. R. Perry and John A. Hawley

Exercise Metabolism: Fuels for the Fire Mark Hargreaves and Lawrence L. Spriet

Health Benefits of Exercise Gregory N. Ruegsegger and Frank W. Booth

Molecular Regulation of Exercise-Induced Muscle

Fiber Hypertrophy

Marcas M. Bamman, Brandon M. Roberts and Gregory R. Adams

Physiological Redundancy and the Integrative

Responses to Exercise Michael J. Joyner and Jerome A. Dempsey

On the Run for Hippocampal Plasticity C'iana Cooper, Hyo Youl Moon and Henriette van Praag

Molecular Basis for Exercise-Induced Fatigue: The Importance of Strictly Controlled Cellular $\mathrm{Ca}$

2+ Handling

Arthur J. Cheng, Nicolas Place and Håkan

Westerblad
Effects of Exercise and Aging on Skeletal Muscle Giovanna Distefano and Bret $H$. Goodpaster

Muscle-Adipose Tissue Cross Talk Kristin I. Stanford and Laurie J. Goodyear

Performance Fatigability: Mechanisms and Task Specificity

Sandra K. Hunter

Adaptations to Endurance and Strength Training David C. Hughes, Stian Ellefsen and Keith Baar

The Bioenergetics of Exercise

$P$. Darrell Neufer

Effects of Exercise on Vascular Function,

Structure, and Health in Humans

Daniel J. Green and Kurt J. Smith

Control of Muscle Metabolism by the Mediator

Complex

Leonela Amoasii, Eric N. Olson and Rhonda

Bassel-Duby

Theoretical and Biological Evaluation of the Link between Low Exercise Capacity and Disease Risk Lauren Gerard Koch and Steven L. Britton

For additional articles in this collection, see http://perspectivesinmedicine.cshlp.org/cgi/collection/ 